\title{
Current Trends in
}

\section{The Fire at Notre-Dame: Roof}

\author{
Jacques Heyman* \\ Cambridge University, United Kingdom
}

\author{
* Corresponding author: Jacques Heyman, Department of Civil Engineering, Cambridge \\ University, United Kingdom.
}

\author{
Received Date: May 24, 2019 \\ Published Date: June 03, 2019
}

\section{Opinion}

The double roof system of the typical Gothic great church-a stone vault surmounted by a timber roof-is both decorative and functional. The steep external roof provides the necessary weather proofing dictated by northern climates (shallow pitches were used for Greek temples); indeed the stone vault, perhaps cracked and in any case not waterproof, itself needs the protection of the outer roof (in Cyprus the Crusader churches, for example Famagusta, hardly need this cover). However timber burns well, and one function of the stone vault is to provide a fire-resistant barrier between the outer roof and the church. There is thus a symbiotic action between the two coverings of the church; the timber roof protects the stone vault and the church from the weather, and the stone vault protects the church from the potential fire hazard of the timber roof. This dual action was very evident in the fire of 15 April 2019 of Notre-Dame of Paris. Severe damage was done, but this would have been very much worse if the "fire-proofing" had not been effective. The videos of the conflagration show the whole of the roofs on fire, but in fact the falling timbers were largely caught by the masonry vaults. It seems that collapse of the vaults occurred in only three locations - the last bay of the north transept, one bay in the nave, and the (roughly) square vault at the crossing. This last was inevitable because of the spectacular collapse of the 500-ton lead-covered oak spire (the flèche) over the crossing.

Gothic construction is dated conventionally as starting in 1140 , with the building of the abbey church of Saint-Denis. The two outstanding characteristics of gothic are the masonry rib vault and the flying buttress, and both are insistently evident at Notre-Dameagain, one cannot exist without the other. A stone vault is in the engineering sense a sort of three-dimensional arch, and all arches thrust outward at their abutments. If there are no side aisles, as at King's College Chapel in Cambridge, then massive buttresses may be built, bay by bay, against the walls of the church. If, however, there are side aisles to the nave and choir, then such buttresses would obstruct those aisles. Hence the thrusts from the high stone vaults are collected by the flying buttresses, and "flown" over the aisles to heavy masonry placed outside the church. Building of Notre-Dame started about the middle of the twelfth century, a little later than Saint-Denis. But Notre-Dame is unusual in that it has two side aisles on either side of the nave and choir, and the original design had a two-span flying buttress system, with intermediate piers between the two aisles. This is not today's construction; it was modified a century later by the removal of the intermediate piers, and replacement by the gigantic 15-metre span fliers which are such a feature of the present external appearance of the cathedral. There was little structural change to the cathedral in the ensuing centuries, although successive kings of France made significant alterations to the internal ordering of the church. But the fabric deteriorated slowly - the thirteenth century flèche over the crossing, for example, had to be taken down in 1792. In any case, the Revolution had occurred in 1789 , and the new regime was actively anti-clerical, and wished to secularize the cathedral; little was done to maintain the integrity of the building. The ruinous state is described in Victor Hugo's 1831 Notre-Dame de Paris.

Public awareness was aroused, and in 1844 a massive restoration programme was initiated, which took 20 years to complete; the work was mainly under the direction of Viollet-leDuc. He had already restored the Sainte-Chapelle, and it was he who designed the new lead-covered timber spire which collapsed over the crossing on 15 April. It may be conjectured that the main roofs which burned on that date had been subject to restoration and renewal by Violet. This is the history - discussion has already started about how the cathedral should be repaired. Cathedrals in England all have fire breaks down their lengths between the timber and stone roofs, and major conflagrations such as that at NotreDame (which appears to have had no such breaks) have been rare. However there has been fairly recent experience after the 1984 destruction of the timber roof of the south transept of York Minster. This cathedral is perhaps unique in England in having no stone 
vaults, and it has been subject to successive conflagrations, of which the 1984 fire was the latest. There was fierce argument about the replacement of the roof of the south transept - the "engineers" thought that a steel truss should be used (hidden from the outside by the roof covering and from the inside by the reconstructed timber ceiling), while the "traditionalists" insisted that oak should be used. (Cologne Cathedral, when it was completed in the nineteenth century after a long intermission in building, made extensive use of iron). The traditionalists won the argument at York. In the event, no oak rafters could be found having sufficient length, so that the restored roof has a triangulated oak cap and is not a faithful reproduction of an original medieval design.

There is some fire damage to the masonry of Notre-Dame, and experienced stone masons will be needed. France will certainly be able to supply these, in contrast to recent experience in Australia. The cathedral in Brisbane, to the design of John Loughborough Pearson, was completed just at the start of the present century after 100 years of construction; it was necessary to involve masons trained in England. However, the Australian experience shows ways in which modern techniques can markedly reduce the number of skilled masons needed. For example, the dimensions of a block of stone required for a masonry column were sent electronically to the quarry 50 miles from Brisbane; these numbers formed the instructions for a numerically-controlled machine, so that the stone could be delivered to site ready cut (actually a millimeter or so oversize so that it could be hand-dressed on installation). (Such prefabrication in the quarry is not new. The Caen stone for the rebuilding of Canterbury Cathedral in the twelfth century, after the fire, was shipped ready-sized across the English Channel). It is likely that a traditional solution will be adopted for the restoration of Notre-Dame, but one area in which there might be innovation lies in the crossing. Something other than a 500-ton flèche could be designed, and there have already been suggestions. It would probably have to be something unexpected, like Pei's pyramid at the Louvre-which is outrageous, but it works.

\section{Acknowledgment}

None.

\section{Conflict of Interest}

No conflict of interest. 